Article

\title{
Optimization of an Ultrasonic-Assisted Biodiesel Production Process from One Genotype of Rapeseed (TERI (OE) R-983) as a Novel Feedstock Using Response Surface Methodology
}

\author{
Sara Almasi ${ }^{1}$, Barat Ghobadian ${ }^{1, *}$, Gholam Hassan Najafi ${ }^{1}$, Talal Yusaf ${ }^{2,3}$, \\ Masoud Dehghani Soufi ${ }^{4}$ and Seyed Salar Hoseini ${ }^{1}$ \\ 1 Department of Mechanical \& Biosystems Engineering, Tarbiat Modares University, \\ Tehran P.O. Box 14115-336, Iran \\ 2 Office of the Pro Vice-Chancellor, Federation University, Ballarat, VIC 3350, Australia \\ 3 Department of Mechanical and Electrical Engineering, University of Southern Queensland, \\ Toowoomba QLD 4350, Australia \\ 4 Department of Agrotechnology, College of Abouraihan, University of Tehran, Tehran 3391-6537-55, Iran \\ * Correspondence: Ghobadib@modares.ac.ir; Tel.: +98-912-113-5306; Fax: +98-214-829-2200
}

Received: 28 April 2019; Accepted: 24 June 2019; Published: 10 July 2019

check for updates

\begin{abstract}
In recent years, due to the favorable climate conditions of Iran, the cultivation of rapeseed has increased significantly. The aim of this study was to investigate the possibility of biodiesel production from one genotype of rapeseed (TERI (OE) R-983). An ultrasonic approach was used in order to intensify the reaction. Response surface methodology (RSM) was applied to identify the optimum conditions of the process. The results of this research showed that the conversion of biodiesel was found to be $87.175 \%$ under the optimized conditions of a $4.63: 1$ molar ratio (methanol to oil), $56.50 \%$ amplitude, and $0.4 \mathrm{~s}$ pulses for a reaction time of $5.22 \mathrm{~min}$. Increasing the operating conditions, such as the molar ratio from $4: 1$ to $5.5: 1$, amplitude from $50 \%$ to $72.5 \%$, reaction time from $3 \mathrm{~min}$ to $7 \mathrm{~min}$, and pulse from $0.4 \mathrm{~s}$ to $1 \mathrm{~s}$, increased the FAME (fatty acid methyl esters) yield by approximately $4.5 \%, 2.3 \%, 1.2 \%$, and $0.5 \%$, respectively. The properties of the TERI (OE) R-983 methyl ester met the requirements of the biodiesel standard (ASTM D6751), indicating the potential of the produced biodiesel as an alternative fuel.
\end{abstract}

Keywords: TERI (OE) R-983; biodiesel; ultrasonic; RSM; renewable energy; novel feedstock

\section{Introduction}

Diesel engines have acquired significant consideration by automobile manufacturing industries and factories in recent years due to their high thermal efficiency, extremely clean exhaust emission, and better fuel economy [1,2]. The traditional fuel for diesel engines is supplied from nonrenewable resources such as fossil fuels. The use of such types of fuel is associated with many risks, such as being prone to depletion and contributing to global warming through greenhouse gas emissions. Hence, many restrictions have been imposed on the use of such fuels by environmental authorities and international communities in recent years [3,4]. In order to implement the restrictive regulations on the use of fossil fuels, an alternative option must be considered. According to the conducted studies, renewable energies are suitable substitutes for fossil resources [5-7]. One of the attractive alternatives to diesel fuel is biodiesel. Chemistry of biodiesel production is as follow:

After the oil has been prepared, its free fatty acids (FFAs) have to be examined. The presence of free fatty acids (FFAs) in vegetable oils leads to formation of soap and reduces the efficiency of methyl ester 
conversion as a result. Researchers have found that FFA $>1 \%$ is undesirable since free fatty acids (FFAs) cause soap formation in the process of base-catalyzed transesterification; thus, an increase in the free fatty acids (FFAs) hinders the removal of biodiesel, glycerin and water in biodiesel production process. The esterification reaction is used to reduce the free fatty acids (FFAs). Esterification is a reaction between the oil and the acid catalyst and causes the free fatty acids (FFAs) to decrease [8]. Sulfuric acid (as an acid catalyst) and methanol are usually used in the esterification process. An acid number of less than unity shows that the free fatty acids (FFAs) content is rather low and the oil can be used as a feedstock with high certainty. After the oil has been acknowledged in terms of the free fatty acids (FFAs) content, the transesterification reaction is performed to improve the mechanical and chemical properties of the oil [9]. Transesterification is a reaction between alcohol and vegetable oil in presence of an acidic, alkali and enzyme catalyst. Moreover, mostly methanol is used in the transesterification reaction to break the triglyceride bonds. As a result, fatty acid methyl esters (FAME) are produced upon the completion of the transesterification reaction [10].

Due to its low contamination during combustion, biodiesel has been utilized considerably in recent years [6,11-14]. Various methods have been investigated in order to produce biodiesel [15]. One of the shortcomings of the conventional method of biodiesel production is its high energy consumption [16]. Using ultrasonic systems is one of the strategies adopted to reduce the energy demand for biodiesel production, which has been studied by various researchers [17-19]. Some of the conducted studies are discussed below.

Teixeira et al. [20] used two methods of biodiesel production - the conventional method and the one involving use of an ultrasonic system - to produce biodiesel from beef tallow. In this study, using ultrasound irradiation ( $400 \mathrm{~W}, 24 \mathrm{kHz}$ ), transesterification of beef tallow was performed with methanol and in the presence of potassium hydroxide as a catalyst. In this study, the reaction time, the conversion percent, and the quality of the biodiesel produced using the ultrasound system were compared with the conventional method. The results showed that using ultrasound irradiation reduces the reaction time, while the conversion percent and the quality of the biodiesel were the same as those of the conventional method. Kumar et al. [21] investigated the effect of using ultrasound irradiation on decreasing the reaction time of biodiesel production from coconut oil. The results of their study indicated that using ultrasound irradiation reduces the reaction time by $15-40 \mathrm{~min}$. Manh et al. [22] studied the effect of ultrasound irradiation on the transesterification yield of biodiesel produced from Tung (Vernicia fordii) and biodiesel produced from different blended oils. In this study, the properties of the produced biodiesel, including the acid value (AV), iodine value (IV), kinematic viscosity (KV), density, and cold filter plugging point (CFPP), were evaluated. Results showed that during the use of ultrasound irradiation, the transesterification yields of biodiesel obtained from Tung and biodiesel produced from blended oils were $91.15 \%$ and $94.03 \%$, respectively. Also, the results showed that the time required to produce high-quality biodiesel using ultrasound irradiation is $30 \mathrm{~min}$, which is a very short time compared to the time needed in conventional biodiesel production. Tamilarasan and Sahadevan [23] used an ultrasonic system to study the optimum conditions for biodiesel production from algal oil from the marine macroalgae Caulerpa peltata. Results showed that using the ultrasonic system, the reaction time considerably reduces with respect to the conventional method. Also, the results indicated that optimum conditions are achievable when: the concentration of sulfuric acid $\left(\mathrm{H}_{2} \mathrm{SO}_{4}\right)$ is $2 \mathrm{wt} \%$, the methanol-to-oil molar ratio is $15: 1$, the reaction time is $30 \mathrm{~min}$, the temperature is at $65{ }^{\circ} \mathrm{C}$, and the stirrer speed is equal to $500 \mathrm{rpm}$. Maghami et al. [24] compared biodiesel fuel production from waste fish oil (WFO) using conventional transesterification and assisted transesterification with ultrasound. Results of this study revealed that the optimum conditions for biodiesel production were a $6: 1$ alcohol-to-oil molar ratio, $55^{\circ} \mathrm{C}$, and $1 \% \mathrm{KOH}$. In this condition, biodiesel yields from conventional and ultrasonic methods were $78 \%$ and $79.6 \%$, respectively. In addition, results showed that during the use of the ultrasonic method, the reaction time decreased by $30 \mathrm{~min}$. Samani et al. [18] produced biodiesel from Pistacia atlantica Desf oilseeds with the help of an ultrasonic system. Results obtained from this study showed that increasing amplitude and pulse leads to methyl 
ester content enhancement. Results also indicated that by increasing the reaction time and molar ratio, the methyl ester content increases. In addition to the above, various research works that explored the effect of biodiesel production by ultrasound irradiation on the reduction of reaction time and the energy needed for biodiesel production all revealed that using ultrasound irradiation decreases the reaction time notably [25-35]. In Table A1 (Table A1), recent research in biodiesel production technology is described. Also in Table A1, the biodiesel yield and biodiesel properties of the different feedstocks are described (Appendix A).

Despite the large number of studies that have investigated ultrasonic-assisted biodiesel production, it appears that there has been no thorough study conducted on the use of ultrasound for improving biodiesel production from rapeseed oil.

Rapeseeds are divided into two groups. These categories are based on the percentage of erucic acid: (a) inedible rapeseed with an erucic acid content of over $40 \%$; because of its high erucic acid content, it is toxic, thus is not used as a food, but is used in industry as a fuel and lubricant. For example, the cultivars HNS9801, Crambe, Millennium, and NPN01, among others, are used for industrial use in some countries, such as the USA, Europe, Belgium, and France; (b) edible rapeseed (canola) with an erucic acid of over $2 \%$; this type of rapeseed is not toxic, but is not suitable as a food. Different researchers, via genetic modification and the use of additives, have reduced the content of erucic acid of rapeseed to below $2 \%$. As a result, it was converted into edible rapeseed (canola).

The potential of rapeseed oil in Iran as a biodiesel resource is as follows:

- In terms of canola cultivation, Iran is divided into four climates (the warm climates of the north and south of Iran, fairly cold, and cold). In cold climates, the winter cultivars of rapeseed are cultivated, and in the two warm climates, the spring cultivars are cultivated. So, all provinces of Iran have potential for cultivating rapeseed;

- Rapeseed requires low quantities of water and is appropriate for the climate of Iran;

- Due to its rotation with wheat, barley, and rice, rapeseed is called an economic plant;

- Due to the problems of drought and water scarcity and increasing desertification in Iran, according to the instructions of the Ministry of Agriculture in Iran, farmers must move towards strategic cultivation. One of the strategic products is the cultivation of rapeseed.

Rapeseed cultivation in Iran over the years is shown in Figure 1. Iran has a very high potential for rapeseed cultivation. Therefore, the area under cultivation of rapeseed can be increased to produce biodiesel. Rapeseed can be cultivated in deserted areas that are useless. In this way, biodiesel can be used despite desertification. As a result, environmental pollutants are reduced and the health of humans, animals, and the environment is protected.

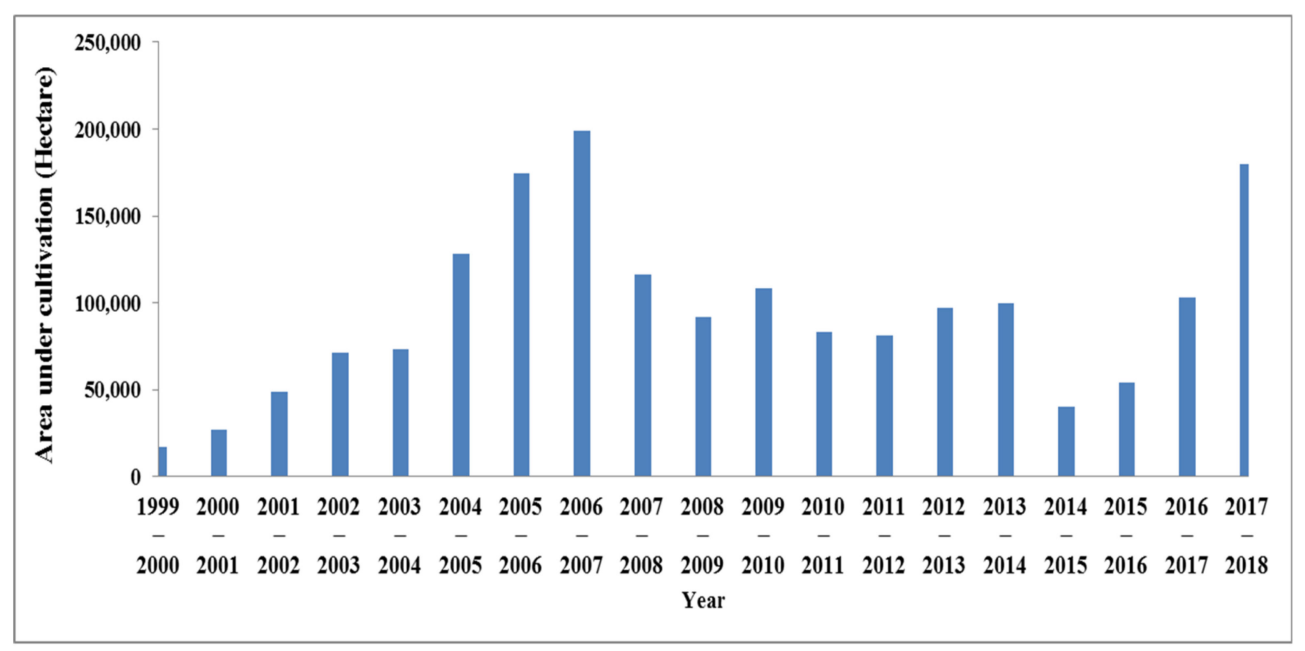

Figure 1. Rapeseed cultivation in Iran over the years. 
Considering the fact that Iran has great potential for rapeseed cultivation, this study was thus designed to study the possibility of biodiesel production by ultrasound irradiation to identify the optimal conditions for biodiesel production using response surface methodology (RSM).

\section{Material and Method}

\subsection{Equipment and Materials}

In this study, one genotype of rapeseed (TERI (OE) R-983) oil was used to produce biodiesel. The TERI (OE) R-983 genotype contains 2-3\% of erucic acid. Thereby, the TERI (OE) R-983 genotype of rapeseed does not have a standard for edibility. Oil was obtained from Jouybar Industrial Park located in Mazandaran province. High-purity $\mathrm{KOH}$ and methanol (99\%) were used to prepare the biodiesel (these materials were sourced from Mina Tajhiz Aria Co., Tehran, Iran). All other chemicals used in this study were obtained from Merck Chemical Industries. Fatty acids and methyl esters (FAMEs) were analyzed by Gas chromatography (GC).

An ultrasonic system (Hielscher Model UP400S), that was provided by Farasout Sanat Engineering Co., Tehran, Iran, was used to do the transesterification process. The ultrasonic system used in this study is shown in Figure 2. The system consisted of a processor, a sonotrode, and a Personal computer (PC) controller. The ultrasonic probe is made of a titanium tip with a diameter of $7 \mathrm{~mm}$ and a length of approximately $100 \mathrm{~mm}$. The applied operating parameters of the used ultrasonic system were $400 \mathrm{~W}$ and $24 \mathrm{kHz}$.

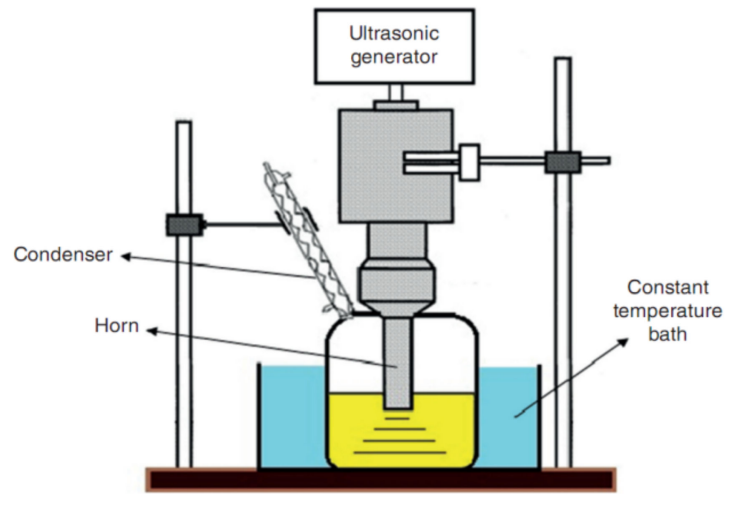

(a)

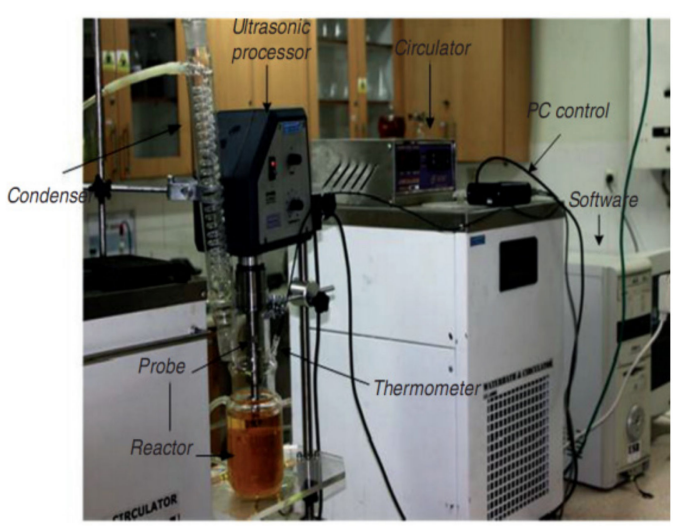

(b)

Figure 2. The biodiesel production set-up: (a) schematic; (b) device [36].

\subsection{Esterification of TERI (OE) R-983 Oil}

Esterification was applied to reduce the acid value content of TERI (OE) R-983 oil. Sulfuric acid ( $1 \mathrm{wt.} \%$ ) was used as a catalyst for the esterification reaction. An appropriate methanol-to-oil molar ratio $(M R)$ was applied to reduce the FFA content $(M R=9)$. Sulfuric acid was added to methanol and the mixture was heated to $50^{\circ} \mathrm{C}$ using a heater. Later, the oil was poured to a jacketed glass reactor and was then heated to $60^{\circ} \mathrm{C}$. Thereupon, the acid and methanol mixture was added to the oil to drive the esterification reaction. After that, the mixture was transferred to a separator and after $24 \mathrm{~h}$, the mixture separated into two phases: the top layer was unused methanol and acid, and the bottom layer was the oil. After separating the oil from the unused methanol and acid, the oil's acid number was measured and was found to be equal to $0.45 \mathrm{mg} \mathrm{KOH} / \mathrm{g}$ oil, which is an appropriate amount for the transesterification reaction [37].

\subsection{Analysis of Fatty Acids Structure}

The Metcalfe method [38] was applied to identify the structure of the oil. The steps of the process were as follows: 
About $50 \mathrm{mg}$ of oil was added to a $15 \mathrm{~mL}$ test tube. Five milliliters of a methanol/soda mixture $\left(\mathrm{NaOH}\right.$ solution $(2 \%)$ in methanol) was prepared. The solution was sited in boiling water $\left(100{ }^{\circ} \mathrm{C}\right)$ for $10 \mathrm{~min}$. After the solution cooled down, $2.175 \mathrm{~mL}$ of boron trifluoride $\left(\mathrm{BF}_{3}\right) 20 \%$ was added and it then was placed again in the boiling water for $3 \mathrm{~min}$. As soon as the solution was cooled down, $1 \mathrm{~mL}$ of n-heptane was added to it, and next, the solution was mixed on an orbital shaker. After that, to separate the organic phase containing methyl esters of fatty acids, $1 \mathrm{~mL}$ of saturated $\mathrm{NaCl}$ salt acid was added to the solution, and the solution was mixed again on the shaker. Then, the fatty acid phase separated from the solution was transferred into a new microtube. Finally, gas chromatography with a Clarus 580 GC (Perkin Elmer Co., Waltham, United States of America) was used to determine the fatty acid structure. After methylation of oil, $1 \mu \mathrm{L}$ of the solution was injected into the Clarus 580. High-purity helium $(99.99 \%)$ was used as the carrier gas. The temperatures of the injection port and the detector were set to be $250{ }^{\circ} \mathrm{C}$ and $300^{\circ} \mathrm{C}$, respectively.

The following temperature program for the column of the Clarus 580 was employed: $170{ }^{\circ} \mathrm{C}$ for $4 \mathrm{~min}$, held at $180^{\circ} \mathrm{C}$ for $0.2 \mathrm{~min}$ after ramping at $3^{\circ} \mathrm{C} / \mathrm{min}$, and held at $210^{\circ} \mathrm{C}$ for $25 \mathrm{~min}$ after ramping at $1{ }^{\circ} \mathrm{C} / \mathrm{min}$. Flame ionization detection (FID) was used as a detector. The total run time for a single sample was about $40 \mathrm{~min}$ [38]. Table 1 shows the fatty acid profile of TERI (OE) R-983 oil.

Table 1. Fatty acid profile of TERI (OE) R-983 oil.

\begin{tabular}{ccc}
\hline Properties & Unit & Amount \\
\hline Palmitic (C16:0) & wt. $\%$ & 4.30 \\
Palmitoleic (C16:1) & wt.\% & 0.19 \\
Stearic (C18:0) & $w t . \%$ & 2.21 \\
Oleic (C18:1) & $w t . \%$ & 65.94 \\
Linoleic (C18:2) & wt. $\%$ & 17.32 \\
Linolenic (C18:3) & wt. $\%$ & 6.05 \\
Other fatty acids & wt. $\%$ & 3.99 \\
Mean molecular weight of used oil & gr/mol & 882.92 \\
Acid value & mg KOH/g oil & 0.57 \\
\hline
\end{tabular}

\subsection{Transesterification}

To do transesterification, methanol and potassium hydroxide were mixed for 5 min using a magnetic stirrer. The formed methoxide was then transferred to a conical flask and mixed with TERI (OE) R-983 oil. Then, the prepared mixture was transferred into the ultrasonic system for treatment. Ultrasound parameters, such as reaction time, amplitude, and pulse, were controlled by a PC controller. During the experiments, the reaction temperature and catalyst concentration were maintained at $55^{\circ} \mathrm{C}$ and $1 \mathrm{wt} . \%$, respectively.

\subsection{FAME Yield Calculation and Statistical Analysis}

After analyzing the fatty acid methyl esters (FAMEs) by GC, the FAME yield of each of the transesterification process' steps were calculated by applying Equations (1)-(3):

$$
\text { FAME content }(\%)=\frac{\left[\sum A\right]-A_{i}}{A_{i}} \times \frac{m_{i}}{M} \times 100 ;
$$

$$
\begin{aligned}
& \text { Amount of FAME }(\mathrm{g})=\text { FAME content }(\%) \times \text { weight of product }(g) ; \\
& \text { Biodiesel yield }(\%)=100 \times \frac{\text { amount of FAME }(\mathrm{g})}{\text { amount of none }- \text { edible canola }(\mathrm{g})} ;
\end{aligned}
$$

where FAME = produced methyl esters weight; $A_{i}=$ peak area of internal standard; $M=$ weight of biodiesel phase in the reaction mixture; $\sum A$ total peaks area of chromatogram; $m_{i}=$ weight of biodiesel for GC analysis. 
One of the goals of this study was to determine the optimum conditions for biodiesel production. To achieve this purpose, the RSM method was applied using Design Expert software. In this study, four independent variables-molar ratio, amplitude, time, and pulse-were investigated. The selected independent variables and their levels are shown in Table 2.

Table 2. Selected independent variables in the response surface method.

\begin{tabular}{cccccc}
\hline & & & \multicolumn{3}{c}{ Level of Each Factor } \\
\cline { 4 - 6 } Independent Variables & Units & Symbols & \multicolumn{3}{c}{ Coded Values } \\
\cline { 4 - 6 } & & & $\mathbf{- 1}$ & $\mathbf{0}$ & $\mathbf{1}$ \\
\hline Molar Ratio & - & $\mathrm{X} 1$ & 4 & 5 & 6 \\
Reaction Time & $\min$ & $\mathrm{X} 2$ & 3 & 5 & 7 \\
Pulse & $\mathrm{S}$ & $\mathrm{X} 3$ & 0.4 & 0.7 & 1 \\
Amplitude & $\%$ & $\mathrm{X} 4$ & 50 & 65 & 80 \\
\hline
\end{tabular}

Design Expert software was used to design a table of randomized runs as illustrated in Table 3.

Table 3. Design experiments.

\begin{tabular}{|c|c|c|c|c|c|c|}
\hline Random & Run & Molar Ratio & Reaction Time & Pulse & Amplitude & Reposes (Yield) \\
\hline 16 & 1 & $5: 1$ & 7 & 1 & 65 & 84.47 \\
\hline 17 & 2 & $4: 1$ & 5 & 0.4 & 65 & 84.77 \\
\hline 26 & 3 & $5: 1$ & 5 & 0.7 & 65 & 85.5 \\
\hline 3 & 4 & $4: 1$ & 7 & 0.7 & 65 & 86.04 \\
\hline 6 & 5 & $5: 1$ & 5 & 1 & 50 & 88.62 \\
\hline 22 & 6 & $5: 1$ & 7 & 0.7 & 50 & 87 \\
\hline 15 & 7 & $5: 1$ & 3 & 1 & 65 & 86.69 \\
\hline 27 & 8 & $5: 1$ & 5 & 0.7 & 65 & 88.34 \\
\hline 18 & 9 & $6: 1$ & 5 & 0.4 & 65 & 86.6 \\
\hline 4 & 10 & $6: 1$ & 7 & 0.7 & 65 & 88.49 \\
\hline 9 & 11 & $4: 1$ & 5 & 0.7 & 50 & 83.8 \\
\hline 8 & 12 & $5: 1$ & 5 & 1 & 80 & 87.6 \\
\hline 23 & 13 & $5: 1$ & 3 & 0.7 & 80 & 88.07 \\
\hline 14 & 14 & $5: 1$ & 7 & 0.4 & 65 & 88.53 \\
\hline 7 & 15 & $5: 1$ & 5 & 0.4 & 80 & 88.19 \\
\hline 12 & 16 & $6: 1$ & 5 & 0.7 & 80 & 86.51 \\
\hline 10 & 17 & $6: 1$ & 5 & 0.7 & 50 & 86.21 \\
\hline 29 & 18 & $5: 1$ & 5 & 0.7 & 65 & 88.33 \\
\hline 19 & 19 & $4: 1$ & 5 & 1 & 65 & 86.42 \\
\hline 11 & 20 & $4: 1$ & 5 & 0.7 & 80 & 84.46 \\
\hline 21 & 21 & $5: 1$ & 3 & 0.7 & 50 & 87.51 \\
\hline 20 & 22 & $6: 1$ & 5 & 1 & 65 & 87.12 \\
\hline 1 & 23 & $4: 1$ & 3 & 0.7 & 65 & 84.5 \\
\hline 28 & 24 & $5: 1$ & 5 & 0.7 & 65 & 87.42 \\
\hline 24 & 25 & $5: 1$ & 7 & 70 & 80 & 87.24 \\
\hline 13 & 26 & $5: 1$ & 3 & 0.4 & 65 & 87.67 \\
\hline 25 & 27 & $5: 1$ & 5 & 0.7 & 65 & 87.7 \\
\hline 2 & 28 & $6: 1$ & 3 & 0.7 & 65 & 86.29 \\
\hline 5 & 29 & $5: 1$ & 5 & 0.4 & 50 & 87.92 \\
\hline
\end{tabular}




\section{Result and Discussion}

\subsection{Statistical Analysis}

Design Expert(R) software proposed the polynomial quadratic model. The statistical analysis was performed on this model. The suggested model is dependent on analysis of variance (ANOVA) and is based on the coded values of the experimental factors (Table 3), as offered by Equation (4).

$$
\begin{aligned}
& \text { Conversion }(\%)=88.06+1.00 \times \mathrm{A}+0.42 \times \mathrm{B}+0.10 \times \mathrm{C}+0.14 \times \mathrm{D}+0.17 \times \mathrm{A} \times \mathrm{B}-0.28 \\
& \times \mathrm{A} \times \mathrm{C}-0.27 \times \mathrm{A} \times \mathrm{D}+0.23 \times \mathrm{B} \times \mathrm{C}-0.080 \times \mathrm{B} \times \mathrm{D}-0.32 \times \mathrm{C} \times \mathrm{D}-2.05 \times \mathrm{A}^{2}-0.050 \\
& \times \mathrm{B}^{2}+0.21 \times \mathrm{C}^{2}-0.56 \times \mathrm{D}^{2}
\end{aligned}
$$

where A, B, C, D are molar ratio (methanol to oil), reaction time (min), the pulse(s), and amplitude (\%) respectively. Table 5 shows the suggested model by RSM. The results of the variance examination of the RSM model are shown predicated on the ANOVA examination in Table 4. As shown in Table 5, the possibility value ( $p$ value) for the model is significantly less than 0.01 . Therefore, ANOVA implies that the model is statistically significant. Corresponding to Table 5 , it is obvious that the effects of molar ratio (methanol to oil) and time have a substantial influence on biodiesel production. The discussion of the relationship between the molar ratio (methanol to oil) and reaction time is significant. Other factors do not have a significant effect on biodiesel yield.

Table 4. Quadratic model statistics.

\begin{tabular}{cccccccc}
\hline Statistical Model & Std. Dev. & $\mathbf{C V}^{*} \%$ & $\mathbf{R}^{\mathbf{2}}$ & Adjusted $\mathbf{R}^{\mathbf{2}}$ & Predicted $\mathbf{R}^{\mathbf{2}}$ & PRESS & Result of Model \\
\hline Linear & 3.81 & 4.63 & 0.6836 & 0.6309 & 0.5501 & 495.97 & \\
2FI ** & 3.73 & 4.53 & 0.7732 & 0.6472 & 0.4557 & 600.00 & \\
Quadratic & 2.67 & 3.24 & 0.9096 & 0.8692 & 0.5040 & 546.77 & Suggested \\
Cubic & 1.72 & 2.09 & 0.9839 & 0.9251 & -0.4745 & 1625.41 & Aliased \\
\hline
\end{tabular}

${ }^{*}$ Coefficient of variation, ${ }^{* *}$ two factor interaction.

Table 5. ANOVA table of model.

\begin{tabular}{cccccc}
\hline Source & Sum of Squares & df & Mean Square & F Value & $p$ Value Prob $>$ F \\
\hline Model & 46.55496 & 14 & 3.325354 & 4.7904466 & 0.0030 \\
Molar ratio (A) & 11.90818 & 1 & 11.90818 & 17.154709 & 0.0010 \\
Reaction time (B) & 2.1168 & 1 & 2.1168 & 3.0494248 & 0.1027 \\
Pulse (C) & 0.128133 & 1 & 0.128133 & 0.1845866 & 0.6740 \\
Amplitude (D) & 0.250563 & 1 & 0.250563 & 0.3609566 & 0.5576 \\
A-B interaction effects & 0.1089 & 1 & 0.1089 & 0.1568794 & 0.6980 \\
A-C interaction effects & 0.319225 & 1 & 0.319225 & 0.4598699 & 0.5087 \\
A-D interaction effects & 0.293764 & 1 & 0.293764 & 0.4231913 & 0.5259 \\
B-C interaction effects & 0.2116 & 1 & 0.2116 & 0.3048272 & 0.5896 \\
B-D interaction effects & 0.0256 & 1 & 0.0256 & 0.0368789 & 0.8505 \\
C-D interaction effects & 0.416025 & 1 & 0.416025 & 0.5993183 & 0.4517 \\
A & 27.29715 & 1 & 27.29715 & 39.323791 & $<0.0001$ \\
B $^{2}$ & 0.016001 & 1 & 0.016001 & 0.0230504 & 0.8815 \\
C $^{2}$ & 0.293825 & 1 & 0.293825 & 0.4232792 & 0.5258 \\
D & 2.044467 & 1 & 2.044467 & 2.9452233 & 0.1082 \\
Residual & 9.718292 & 14 & 0.694164 & & \\
Lack of Fit & 8.834212 & 10 & 0.883421 & 3.9970191 & 0.0970 \\
Pure Error & 0.88408 & 4 & 0.22102 & & \\
Cor Total & 56.27325 & 28 & & & \\
\hline
\end{tabular}

\subsection{Effects of Molar Ratio and Reaction Time on FAME Yield}

Figure 3 shows the effect of molar ratio and reaction time on FAME yields. It can be seen from Figure 3 that with increasing the molar ratio up to 5.5, FAME yields increase. However, increasing the molar ratio over this level leads to a reduction in FAME yields. The main reason for this is 
the increasing amount of methanol in the mixture, which leads to more dissolution of glycerin and alcohol in biodiesel [39]. Also, Figure 3 shows that by increasing the reaction time, FAME yields increase. Because the required methanol is available throughout the reaction time, by increasing the reaction time at the different methanol molar ratios, the FAME yield increases. Also, by increasing the molar ratio, higher amounts of alcohol are available to react with the triglycerides, and therefore, the FAME yield will have an increasing trend. At high molar ratios and lower times, due to the lack of sufficient time, the reaction is not completed, thus, the FAME yield decreased.

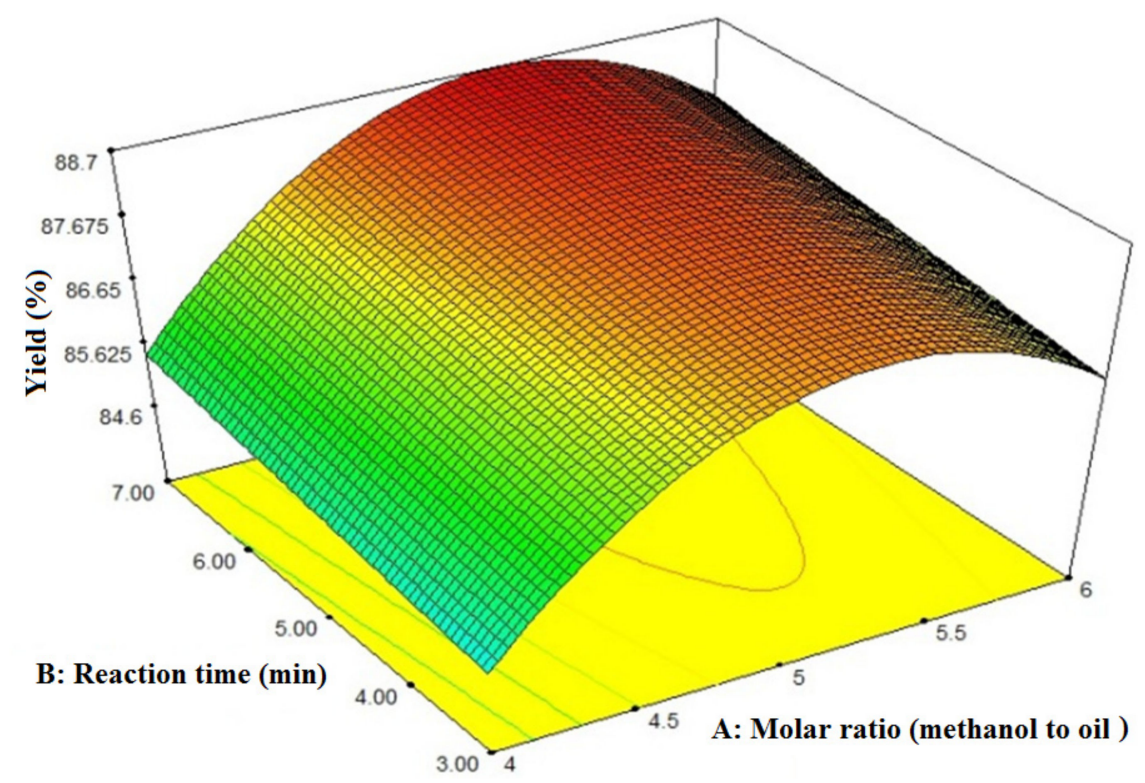

Figure 3. Effect of reaction time and molar ratio on yield (methyl ester content) at a pulse of $0.4 \mathrm{~s}$.

\subsection{Interaction Effects of Pulse and Molar Ratio (Methanol-to-Oil Ratio) on FAME Yield}

The effect of pulse on FAME yield is shown in Figure 4. By increasing the pulse, the FAME yield increases slightly. A higher pulse increases the mixture rate, so mass transfer is highly performed, and therefore the FAME yield increases. It should be noted that if the pulse exceeds a certain amount, the FAME yield increases with a lower slope. It has been proven that if the ultrasonic pulse is less than 1, mass transfer occurs better and less energy is consumed; however, if the pulse value is less than 0.7 , the ultrasonic macrostirring effect is low and cannot mix the immiscible reactants together, and therefore, the yield of biodiesel decreases. Also in Figure 4, the effect of molar ratio on FAME yield is shown. By increasing the molar ratio (methanol-to-oil ratio) to $5.5: 1$ in pulse about $1 \mathrm{~s}$, the yield of FAME increased. However, by increasing the molar ratio (methanol-to-oil ratio) over 5.5:1, the yield of FAME decreased. According to Figure 4, when the molar ratio (methanol-to-oil ratio) is about 5.5:1 and the pulse is about $1 \mathrm{~s}$, the yield of FAME is highest. 


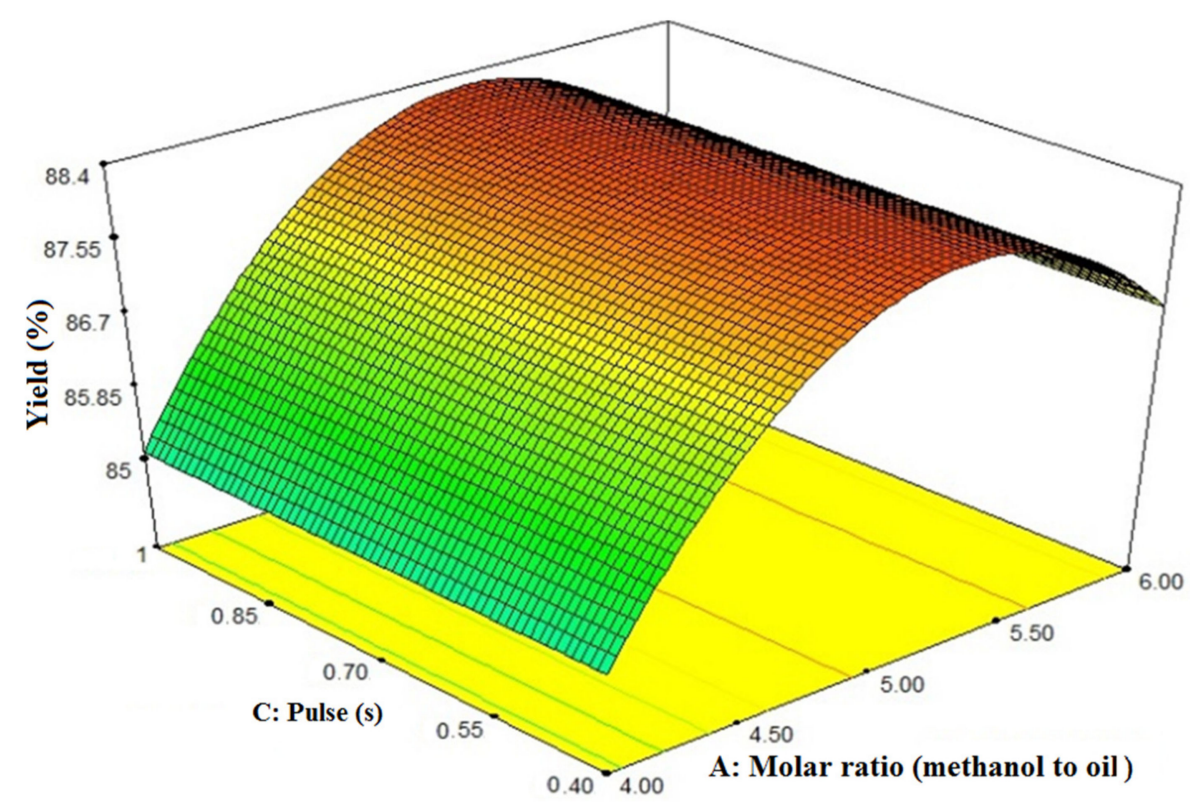

Figure 4. Effect of pulse on yield (methyl ester content) at the reaction time of $5.22 \mathrm{~min}$.

\subsection{Interaction Effects of Amplitude and Molar Ratio (Methanol-to-Oil Ratio) on FAME Yield}

The impact of ultrasonic amplitude on FAME yield is depicted in Figure 5. By increasing the amplitude of acoustic waves, the droplets get smaller in size and the number of circulating bubbles leads to increased mixing of oil and alcohol, thus a better emulsion is generated [38]. As shown in Figure 5 , by increasing the amplitude to about $72.5 \%$, the biodiesel conversion rate increases, and when the amplitude reaches over $72.5 \%$, the amount of FAME yield decreases. The high amplitude increases the cracking; thus, the fatty acid methyl esters oxidized to aldehydes, ketones, and lower-chained organic fractions [40]. Also in Figure 5, the effect of molar ratio on FAME yield is shown. By increasing the molar ratio (methanol-to-oil ratio) to 5.5:1, the yield of FAME increases. However, by increasing the molar ratio (methanol-to-oil ratio) over 5.5:1, the yield of FAME decreased. According to Figure 5, when the molar ratio (methanol-to-oil ratio) is about 5.5:1 and the amplitude is about $74 \%$, the yield of FAME is highest.

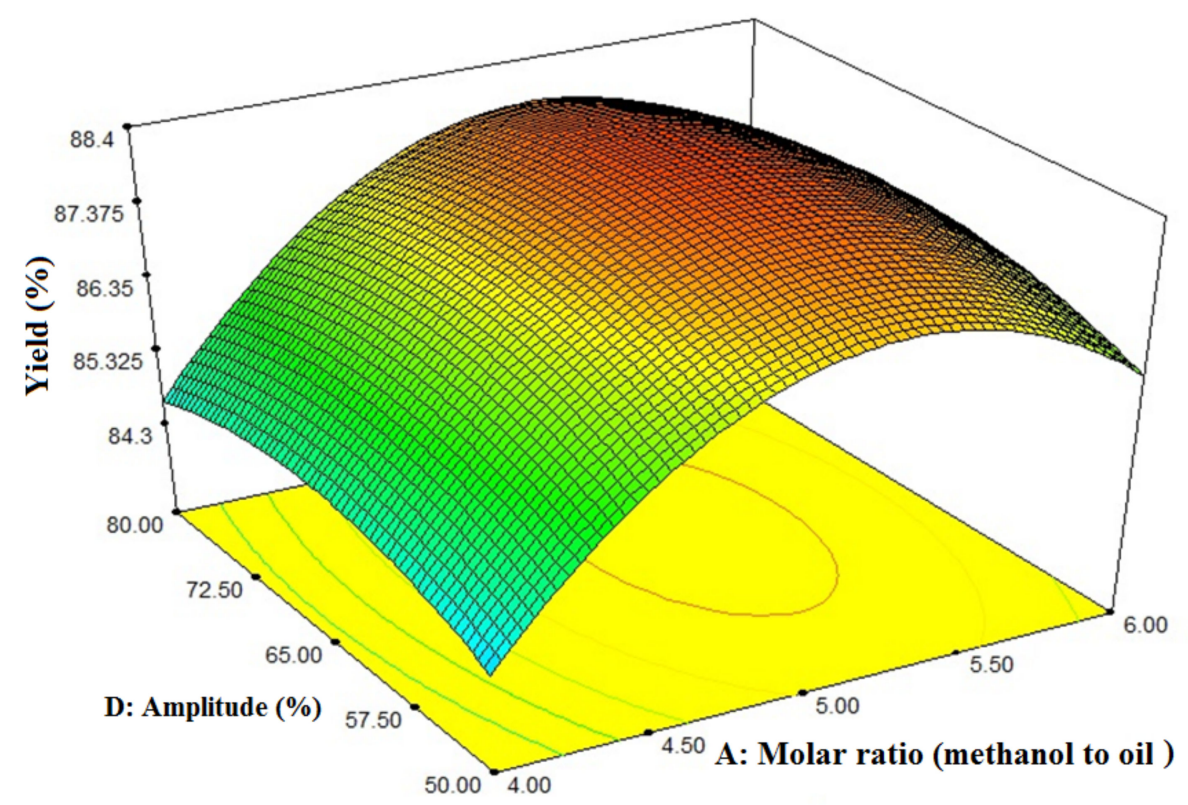

Figure 5. Effect of amplitude on yield (methyl ester content) at a pulse of $0.4 \mathrm{~s}$. 


\subsection{Optimization of the Production Process Using Desirability Function}

The optimal conditions for biodiesel production were predicted using the multifactor desirability function. After the creation of biodiesel and separation of glycerin from the methyl ester, the methyl ester was examined using GC-FID and the most optimal yield was identified. The perfect value for each and every one of the analyzed variables was expected by Equation (4) to be able to get the highest rate of biodiesel alteration. Equation (4) is dependent on the regression polynomial formula, which comes from the response surface technique (RSM) model. The perfect value for each of the factors are as follows:

(a) Molar ratio (methanol to oil) $=4.63: 1$;

(b) Reaction time $=5.22 \mathrm{~min}$;

(c) Pulse $=0.4 \mathrm{~s}$;

(d) Amplitude $=56.50 \%$.

The regression polynomial formula estimates that if the factors acquire these values, the peak of biodiesel yield $(87.175 \%)$ is obtained. To be able to validate the predicted value, the optimized parameters were experimentally analyzed and the biodiesel yield was assessed to be $87.9 \%$. Experimental results confirmed that the worthiness expected by the response surface strategy (RSM) has an excellent agreement with the experimental results, given that the reaction time in this research is short. Thus, the FAME yield is under $95 \%$ in optimized conditions.

\subsection{Properties of the Produced Biodiesel}

Table 6 presents the properties of the biodiesel produced in this study. The properties of the produced methyl ester, including flash point, pour point, kinematic viscosity at $40^{\circ} \mathrm{C}$, density, acid value, and oxidative stability, were measured using the ASTM standard. All the measured properties were then compared with a biodiesel standard (EN 14214). Kinematic viscosity is one of the most important characteristics of a fuel and has a significant impact on the erosion of the engine parts. The main purpose of the esterification or transesterification process is to reduce the viscosity of vegetable oils. As shown in Table 6, the viscosity is $4.65 \mathrm{~mm}^{2} / \mathrm{s}$, thus, the viscosity of biodiesel produced from TERI (OE) R-983 oil is acceptable. Research results of Hoekman et al. [41] showed that in twelve types of biodiesel, the range of kinematic viscosity was from 4 to $5 \mathrm{~mm}^{2} / \mathrm{s}$.

Table 6. Physicochemical characterization of TERI (OE) R-983 biodiesel.

\begin{tabular}{ccccc}
\hline Properties & Test Method & Limits & Units & Measured Properties \\
\hline Water and sediment & ASTM D2709 & Max 0.05 & $\%$ volume & $<0.004$ \\
Density at $15{ }^{\circ} \mathrm{C}$ & ASTM D4052 & $0.86-0.90$ & $\mathrm{~kg} / \mathrm{cm}^{3}$ & 0.88 \\
Kinematic viscosity at $40^{\circ} \mathrm{C}$ & ASTM D445 & $1.9-6.0$ & $\mathrm{~mm}^{2} / \mathrm{s}$ & 4.65 \\
Oxidation stability & EN 14112 & Min 3 & $\mathrm{h}$ & 3.2 \\
Flash point, closed cup & ASTM D93 & Min 130 & ${ }^{\circ} \mathrm{C}$ & 213 \\
Pour point & ASTM D97 & -15 to 10 & ${ }^{\circ} \mathrm{C}$ & -9 \\
Acid number & ASTM D664 & Max 0.50 & $\mathrm{mg} \mathrm{KOH} / \mathrm{g}$ & 0.29 \\
\hline
\end{tabular}

According to Table 7, it is clear that the flash point, pour point, acid value, and oxidative stability are consistent with reports from other researchers [21,22,42]. It is important to note here that the properties of the produced biodiesel are in the range of the standard-defined properties (ASTM D6751 and EN 14112).

\section{Comparison with the Literature}

In Table 7, the properties of TERI (OE) R-983 biodiesel are compared with those of recently published research studies. The properties of TERI (OE) R-983 biodiesel are similar to the properties of other biodiesels. Density is an important parameter of biodiesel, with an impact on fuel quality. As shown in Table 7, the density of TERI (OE) R-983 biodiesel is less than some of the biodiesel 
types. The specific gravity of biodiesel can have a great impact on the mixing of diesel and biodiesel. The specific gravity of biodiesel fuel should be such that the diesel and biodiesel fuel phases are not separated after mixing.

One of the deficiencies of biodiesel fuel is the high value of viscosity. High viscosity means less fuel atomization, higher resistance to fuel pumping, damage to the fuel filter, poor combustion, and increased exhaust gases [43]. The kinematic viscosity of TERI (OE) R-983 biodiesel is high than some of the biodiesel types. Also, the pour point of TERI (OE) R-983 biodiesel is low, which can be considered an advantage of TERI (OE) R-983 biodiesel compared with some other biodiesel types. Additionally, the oxidation stability of TERI (OE) R-983 biodiesel is better than Kusum biodiesel.

Table 7. Comparison of the properties of TERI (OE) R-983 biodiesel with biodiesels made from other feedstock.

\begin{tabular}{|c|c|c|c|c|c|c|}
\hline Feedstocks & $\begin{array}{c}\text { Density at } 15^{\circ} \mathrm{C} \\
\left(\mathrm{kg} / \mathrm{cm}^{3}\right)\end{array}$ & $\begin{array}{l}\text { Kinematic Viscosity } \\
\text { at } 40^{\circ} \mathrm{C}\left(\mathrm{mm}^{2} / \mathrm{s}\right)\end{array}$ & $\begin{array}{l}\text { Pour Point } \\
\quad\left({ }^{\circ} \mathrm{C}\right)\end{array}$ & $\begin{array}{c}\text { Flash Point } \\
\left({ }^{\circ} \mathrm{C}\right)\end{array}$ & $\begin{array}{l}\text { Acid Value } \\
\text { (mg KOH/g) }\end{array}$ & $\begin{array}{c}\text { Oxidation } \\
\text { Stability (h) }\end{array}$ \\
\hline $\begin{array}{c}\text { Current study } \\
\text { (TERI (OE) R-983) }\end{array}$ & 0.8822 & 4.6481 & -9 & 213 & 0.29 & 3.20 \\
\hline Waste cooking oil [44] & 0.875 & 3.84 & -1 & 164 & 0.27 & - \\
\hline Kusum oil [45] & 0.857 & 5.34 & -2 & 152 & 0.42 & 0.86 \\
\hline Waste cooking oil [46] & 0.888 & 2.35 & -19 & 185 & & - \\
\hline Canola oil [47] & 0.884 & 4.51 & & 184 & & - \\
\hline Rapeseed oil [48] & 0.882 & 4.62 & & 175.5 & 0.41 & - \\
\hline
\end{tabular}

\section{Conclusions}

The feasibility of biodiesel production from one genotype of rapeseed (TERI (OE) R-983) using ultrasound irradiation was investigated, and the optimum conditions for production were identified using RSM. The following results were obtained:

- The molar ratio of alcohol to oil has a positive effect on the transesterification reaction and, consequently, on biodiesel conversion. Increasing the molar ratio from 4:1 to 6:1 increased the FAME yield by approximately $4.5 \%$;

- The optimal value for the FAME yield from TERI (OE) R-983 oil using ultrasound irradiation was $87.175 \%$; the conditions that resulted in this value were: a $4.63: 1$ alcohol-to-oil molar ratio, 5.22 min reaction time, $0.40 \mathrm{~s}$ pulse, and $56.50 \%$ amplitude;

- The properties of the produced biodiesel being within the range of the standard-defined properties (ASTM D6751) highlights the potential of such a biodiesel to be used as an alternative fuel.

Author Contributions: Conceptualization, S.A.; methodology, S.A.; formal analysis, S.A., B.G., G.H.N., S.S.H. and M.D.S.; writing—original draft preparation, S.A., B.G., G.H.N., S.S.H. and M.D.S.; writing—review and editing, S.A., B.G. and G.H.N.; project administration, T.Y.

Funding: This research received no external funding.

Acknowledgments: We thank our colleagues from TMU Renewable Energies Research Institute who provided insight and expertise that greatly assisted this research.

Conflicts of Interest: The authors declare no conflict of interest. 


\section{Appendix A}

Table A1. Biodiesel production technology and properties of biodiesel.

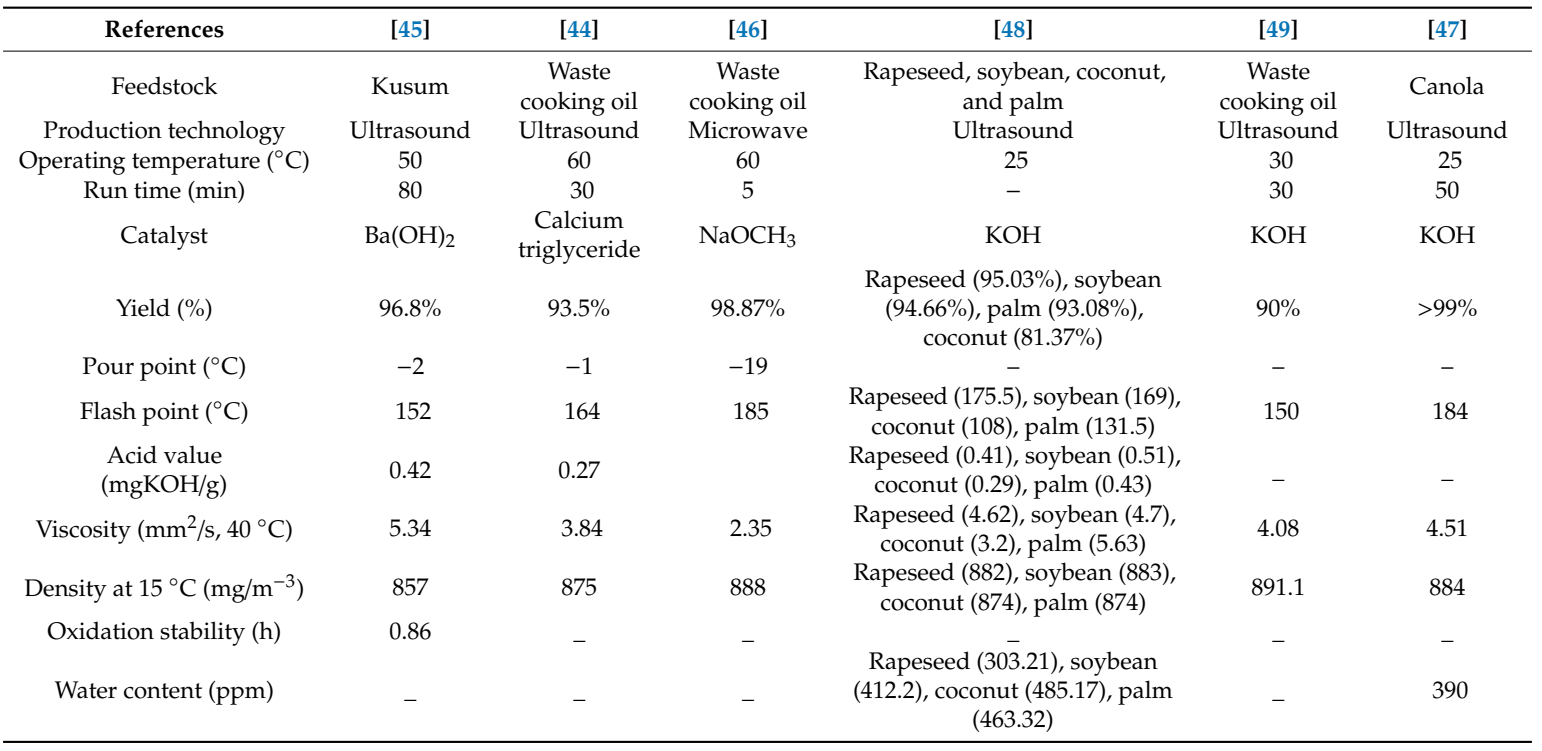

\section{References}

1. Kajitani, S.; Oguma, M.; Mori, T. DME Fuel Blends for Low-Emission, Direct-Injection Diesel Engines; SAE Technical Paper; SAE International: Warrendale, PA, USA, 2000.

2. Wang, J. Hybrid robust air-path control for diesel engines operating conventional and low temperature combustion modes. IEEE Trans. Control Syst. Technol. 2008, 16, 1138-1151. [CrossRef]

3. Ediger, V.Ş.; Kentel, E. Renewable energy potential as an alternative to fossil fuels in Turkey. Energy Conv. Manag. 1999, 40,743-755. [CrossRef]

4. Barbir, F.; Veziroğlu, T.; Plass, H. Environmental damage due to fossil fuels use. Int. J. Hydrog. Energy 1990, 15, 739-749. [CrossRef]

5. Carraretto, C.; Macor, A.; Mirandola, A.; Stoppato, A.; Tonon, S. Biodiesel as alternative fuel: Experimental analysis and energetic evaluations. Energy 2004, 29, 2195-2211. [CrossRef]

6. Huang, D.; Zhou, H.; Lin, L. Biodiesel: An alternative to conventional fuel. Energy Procedia 2012, 16, $1874-1885$. [CrossRef]

7. Gaurav, N.; Sivasankari, S.; Kiran, G.; Ninawe, A.; Selvin, J. Utilization of bioresources for sustainable biofuels: A Review. Renew. Sustain. Energy Rev. 2017, 73, 205-214. [CrossRef]

8. Patil, P.D.; Deng, S. Optimization of biodiesel production from edible and non-edible vegetable oils. Fuel 2009, 88, 1302-1306. [CrossRef]

9. Bilal, S.; Nuhu, M.; Kasim, S. Production of biolubricant from Jatropha curcas seed oil. J. Chem Eng. Mater. Sci. 2013, 4, 72-79.

10. Sajjadi, B.; Raman, A.A.A.; Arandiyan, H. A comprehensive review on properties of edible and non-edible vegetable oil-based biodiesel: Composition, specifications and prediction models. Renew. Sustain. Energy Rev. 2016, 63, 62-92. [CrossRef]

11. Annamalai, $\mathrm{K}$. The status of biodiesel as an alternative fuel for diesel engine-An overview. J. Sustain. Energy Environ. 2011, 2, 71-75.

12. Datta, A.; Mandal, B.K. A comprehensive review of biodiesel as an alternative fuel for compression ignition engine. Renew. Sustain. Energy Rev. 2016, 57, 799-821. [CrossRef]

13. Hoseini, S.; Najafi, G.; Ghobadian, B.; Yusaf, T.; Ebadi, M. The effect of combustion management on diesel engine emissions fueled with biodiesel-diesel blends. Renew. Sustain. Energy Rev. 2017, 73, 307-331. [CrossRef] 
14. Hoseini, S.; Najafi, G.; Ghobadian, B.; Yusaf, T.; Ebadi, M. The Effects of Camelina "Soheil" as a Novel Biodiesel Fuel on the Performance and Emission Characteristics of Diesel Engine. Appl. Sci. 2018, 8, 1010. [CrossRef]

15. Abbaszaadeh, A.; Ghobadian, B.; Omidkhah, M.R.; Najafi, G. Current biodiesel production technologies: A comparative review. Energy Conv. Manag. 2012, 63, 138-148. [CrossRef]

16. Amelio, A.; Van de Voorde, T.; Creemers, C.; Degrève, J.; Darvishmanesh, S.; Luis, P.; Van der Bruggen, B. Comparison between exergy and energy analysis for biodiesel production. Energy 2016, 98, 135-145. [CrossRef]

17. Naderloo, L.; Javadikia, H.; Mostafaei, M. Modeling the energy ratio and productivity of biodiesel with different reactor dimensions and ultrasonic power using ANFIS. Renew. Sustain. Energy Rev. 2017, 70, 56-64. [CrossRef]

18. Samani, B.H.; Zareiforoush, H.; Lorigooini, Z.; Ghobadian, B.; Rostami, S.; Fayyazi, E. Ultrasonic-assisted production of biodiesel from Pistacia atlantica Desf. oil. Fuel 2016, 168, 22-26. [CrossRef]

19. Hoseini, S.S.; Najafi, G.; Ghobadian, B.; Mamat, R.; Ebadi, M.T.; Yusaf, T. Ailanthus altissima (tree of heaven) seed oil: Characterisation and optimisation of ultrasonication-assisted biodiesel production. Fuel 2018, 220, 621-630. [CrossRef]

20. Teixeira, L.S.G.; Assis, J.C.R.; Mendonça, D.R.; Santos, I.T.V.; Guimarães, P.R.B.; Pontes, L.A.M.; Teixeira, J.S.R. Comparison between conventional and ultrasonic preparation of beef tallow biodiesel. Fuel Proc. Technol. 2009, 90, 1164-1166. [CrossRef]

21. Kumar, D.; Kumar, G.; Poonam; Singh, C.P. Fast, easy ethanolysis of coconut oil for biodiesel production assisted by ultrasonication. Ultrason. Sonochem. 2010, 17, 555-559. [CrossRef]

22. Van Manh, D.; Chen, Y.-H.; Chang, C.-C.; Chang, M.-C.; Chang, C.-Y. Biodiesel production from Tung oil and blended oil via ultrasonic transesterification process. J. Taiwan Inst. Chem. Eng. 2011, 42, 640-644. [CrossRef]

23. Tamilarasan, S.; Sahadevan, R. Ultrasonic assisted acid base transesterification of algal oil from marine macroalgae Caulerpa peltata: Optimization and characterization studies. Fuel 2014, 128, 347-355. [CrossRef]

24. Maghami, M.; Sadrameli, S.M.; Ghobadian, B. Production of biodiesel from fishmeal plant waste oil using ultrasonic and conventional methods. Appl. Therm. Eng. 2015, 75, 575-579. [CrossRef]

25. Bhangu, S.K.; Gupta, S.; Ashokkumar, M. Ultrasonic enhancement of lipase-catalysed transesterification for biodiesel synthesis. Ultrason. Sonochem. 2017, 34, 305-309. [CrossRef] [PubMed]

26. Mazanov, S.V.; Gabitova, A.R.; Usmanov, R.A.; Gumerov, F.M.; Labidi, S.; Amar, M.B.; Passarello, J.-P.; Kanaev, A.; Volle, F.; Neindre, B.L. Continuous production of biodiesel from rapeseed oil by ultrasonic assist transesterification in supercritical ethanol. J. Supercrit. Fluids 2016, 118, 107-118. [CrossRef]

27. Choedkiatsakul, I.; Ngaosuwan, K.; Cravotto, G.; Assabumrungrat, S. Biodiesel production from palm oil using combined mechanical stirred and ultrasonic reactor. Ultrason. Sonochem. 2014, 21, 1585-1591. [CrossRef] [PubMed]

28. Chen, G.; Shan, R.; Shi, J.; Yan, B. Ultrasonic-assisted production of biodiesel from transesterification of palm oil over ostrich eggshell-derived CaO catalysts. Bioresour. Technol. 2014, 171, 428-432. [CrossRef]

29. Lee, S.B.; Lee, J.D.; Hong, I.K. Ultrasonic energy effect on vegetable oil based biodiesel synthetic process. J. Ind. Eng. Chem. 2011, 17, 138-143. [CrossRef]

30. Takase, M.; Chen, Y.; Liu, H.; Zhao, T.; Yang, L.; Wu, X. Biodiesel production from non-edible Silybum marianum oil using heterogeneous solid base catalyst under ultrasonication. Ultrason. Sonochem. 2014, 21, 1752-1762. [CrossRef]

31. Manh, D.-V.; Chen, Y.-H.; Chang, C.-C.; Chang, C.-Y.; Hanh, H.-D.; Chau, N.-H.; Tuyen, T.-V.; Long, P.-Q.; Minh, C.-V. Effects of blending composition of tung oil and ultrasonic irradiation intensity on the biodiesel production. Energy 2012, 48, 519-524. [CrossRef]

32. Ji, J.; Wang, J.; Li, Y.; Yu, Y.; Xu, Z. Preparation of biodiesel with the help of ultrasonic and hydrodynamic cavitation. Ultrasonics 2006, 44, e411-e414. [CrossRef] [PubMed]

33. Hanh, H.D.; Dong, N.T.; Okitsu, K.; Nishimura, R.; Maeda, Y. Biodiesel production through transesterification of triolein with various alcohols in an ultrasonic field. Renew. Energy 2009, 34, 766-768. [CrossRef]

34. Yu, D.; Tian, L.; Wu, H.; Wang, S.; Wang, Y.; Ma, D.; Fang, X. Ultrasonic irradiation with vibration for biodiesel production from soybean oil by Novozym 435. Process Biochem. 2010, 45, 519-525. [CrossRef] 
35. Maneechakr, P.; Samerjit, J.; Uppakarnrod, S.; Karnjanakom, S. Experimental design and kinetic study of ultrasonic assisted transesterification of waste cooking oil over sulfonated carbon catalyst derived from cyclodextrin. J. Ind. Eng. Chem. 2015, 32, 128-136. [CrossRef]

36. Fayyazi, E.; Ghobadian, B.; Najafi, G.; Hosseinzadeh, B.; Mamat, R.; Hosseinzadeh, J. An ultrasound-assisted system for the optimization of biodiesel production from chicken fat oil using a genetic algorithm and response surface methodology. Ultrason. Sonochem. 2015, 26, 312-320. [CrossRef] [PubMed]

37. Jain, S. 17 The production of biodiesel using Karanja (Pongamia pinnata) and Jatropha (Jatropha curcas) Oil. In Biomass, Biopolymer-Based Materials, and Bioenergy; Verma, D., Fortunati, E., Jain, S., Zhang, X., Eds.; Woodhead Publishing: Cambridge, UK, 2019; pp. 397-408.

38. Metcalfe, L.; Schmitz, A.A.; Pelka, J. Rapid preparation of fatty acid esters from lipids for gas chromatographic analysis. Anal. Chem. 1966, 38, 514-515. [CrossRef]

39. Hingu, S.M.; Gogate, P.R.; Rathod, V.K. Synthesis of biodiesel from waste cooking oil using sonochemical reactors. Ultrason. Sonochem. 2010, 17, 827-832. [CrossRef] [PubMed]

40. Mostafaei, M.; Ghobadian, B.; Barzegar, M.; Banakar, A. Optimization of ultrasonic assisted continuous production of biodiesel using response surface methodology. Ultrason. Sonochem. 2015, 27, 54-61. [CrossRef] [PubMed]

41. Hoekman, S.K.; Broch, A.; Robbins, C.; Ceniceros, E.; Natarajan, M. Review of biodiesel composition, properties, and specifications. Renew. Sustain. Energy Rev. 2012, 16, 143-169. [CrossRef]

42. Mohamad, M.; Ngadi, N.; Wong, S.L.; Jusoh, M.; Yahya, N.Y. Prediction of biodiesel yield during transesterification process using response surface methodology. Fuel 2017, 190, 104-112. [CrossRef]

43. Özgür, C.; Tosun, E. Prediction of density and kinematic viscosity of biodiesel by artificial neural networks. Energy Sour. Part A Recov. Util. Environ. Eff. 2017, 39, 985-991. [CrossRef]

44. Gupta, A.R.; Yadav, S.V.; Rathod, V.K. Enhancement in biodiesel production using waste cooking oil and calcium diglyceroxide as a heterogeneous catalyst in presence of ultrasound. Fuel 2015, 158, 800-806. [CrossRef]

45. Sarve, A.N.; Varma, M.N.; Sonawane, S.S. Ultrasound assisted two-stage biodiesel synthesis from non-edible Schleichera triguga oil using heterogeneous catalyst: Kinetics and thermodynamic analysis. Ultrason. Sonochem. 2016, 29, 288-298. [CrossRef] [PubMed]

46. Azcan, N.; Yilmaz, O. Microwave assisted transesterification of waste frying oil and concentrate methyl ester content of biodiesel by molecular distillation. Fuel 2013, 104, 614-619. [CrossRef]

47. Thanh, L.T.; Okitsu, K.; Sadanaga, Y.; Takenaka, N.; Maeda, Y.; Bandow, H. Ultrasound-assisted production of biodiesel fuel from vegetable oils in a small scale circulation process. Bioresour. Technol. 2010, 101, 639-645. [CrossRef] [PubMed]

48. Sáez-Bastante, J.; Pinzi, S.; Arzamendi, G.; Luque de Castro, M.D.; Priego-Capote, F.; Dorado, M.P. Influence of vegetable oil fatty acid composition on ultrasound-assisted synthesis of biodiesel. Fuel 2014, 125, 183-191. [CrossRef]

49. Babajide, O.; Petrik, L.; Amigun, B.; Ameer, F. Low-cost feedstock conversion to biodiesel via ultrasound technology. Energies 2010, 3, 1691-1703. [CrossRef]

(C) 2019 by the authors. Licensee MDPI, Basel, Switzerland. This article is an open access article distributed under the terms and conditions of the Creative Commons Attribution (CC BY) license (http://creativecommons.org/licenses/by/4.0/). 